\title{
CHANGE DYNAMICS OF BIOGENIC MATTER IN RIVER WATERS OF SOUTHEAST LITHUANIA DURING PERIODS OF DIFFERENT WATERINESS
}

\author{
Lina Bagdžiūnaitė-Litvinaitienè
}

Dept of Hydraulics, Vilnius Gediminas Technical University, Sauletekio al. 11, LT-10223 Vilnius, Lithuania.E-mail: hk@ap.vtu.lt

Received 13 Oct 2003; accepted 22 Sept 2004

\begin{abstract}
Water protection is one of the most all-round regulated areas of the EU environmental control. In order to prognose the state of water ecosystem it is necessary to evaluate its long-term changes. The paper analyses water quality of three southeast Lithuanian rivers (the Strèva, the Merkys, the Šventoji) during the last three decades. The dependence of river water abundance and biogenic matter (mineral nitrogen and phosphorus) concentrations and amount changes was analysed. By investigating the annual data of biogenic matter concentrations and discharges during the period of 30 years, it is established that there is no dependence. After an additional sampling (3 times a month) of surface waters it is established that the dependence is strong, the coefficient of correlation fluctuates from 0,5 to 0,99 .
\end{abstract}

Keywords: mineral nitrogen, mineral phosphorus, run-off volume, yield.

\section{Introduction}

In order to forecast on water ecosystem condition, it is important to consider key factors that influence the concentrations of biogenic matter. It is also necessary to evaluate long-term changes of climatic, economical and social conditions. In natural geosystems the concentrations and inflow of the most important biogenic elements (mineral nitrogen and mineral phosphorus) are determined by physical and chemical qualities of the soil, climate, and anthropogenic activities. The greatest influence comes from cities and industrial activities which account for the pollution of rivers and lakes together with changes in physical and chemical composition of water. Agricultural and forestry activities determine dispersive pollution which has a significant influence on eutrophication of water reservoirs. Large energy- and transport-associated objects and run-off regulating ponds also change significantly the parameters of water ecosystems.

Over the last 30 years Lithuanian agrarian landscape has changed to a considerable extent. While pursuing an intensive melioration programme, the hydrological regime of rivers has been altered. The structure of water balance of the river basin was changing together with an expansion of the area which was drained and used for agriculture. This resulted in an increase in the evaporation and accumulative potency of the soil, while the volume of water run-off decreased only a little. Even a small alteration of water regime causes inevitable changes in hydrochemical regime.

For Lithuania entering the European Union, a very important and relevant task is to reduce the quantity of nitrates in both surface and ground waters. In order to put The Directive on Nitrates $(91 / 676 /$ EEC) into practice, first it is necessary to evaluate the present situation. That is why papers analysing the hydrochemical state of Lithuanian rivers appear in scientific literature more frequently. Many scientists pay a great regard to studies of agricultural activities that influence the quality of surface waters. Analysis of nitrate concentration change dynamics in Lithuanian rivers in the period 19811994, made by A. S. Šileika [1], shows that since 1990 nitrate concentration was considerably elevated in the waters of river basins which are larger than $100 \mathrm{~km}^{2}$, despite that the use of mineral fertilizers in agriculture was decreased five times since 1989. Among the factors, which may potentially increase water pollution, are inappropriate management of manure, accumulation and decomposition of organic substances in abandoned fields (e g unharvested crops), insufficient farming control causing poor environmental protection, and insufficient education of new farmers. After examining changes in water quality in Lithuanian rivers and grouping them according to change dynamics of nitrate nitrogen concentrations, it is found that a sharp increase in nitrate 
concentration since 1990 was caused by certain anthropogenic activities [2]. However, there are also other opinions. For example, R. Tumas has proposed that water characteristics in different Lithuanian regions might be determined by local natural conditions which influence the run-off of rivers [3]. Therefore, it is important to determine how the quality of water is formed before getting into rivers and how it is affected by different meteorological conditions. Analysis of water quality formation in small rivers of Lithuania show that the chemical regime of a river is formed relatively to its physicalgeographical location. In Middle Lithuania Plain, where the river run-off is mostly formed with surface waters, rivers are mainly polluted by biogenic matter, in contrast to Žemaičiai Heights and East Lithuania, where the wash-out of chemical substances is less intensive. These consistent patterns are determined by different amounts of participation and differences in the process of the river run-off formation.

The quality of river water is determined not only by natural causes, but also by farming activities. However, due to the decline in anthropogenic load on agriculture in recent years, the influence of farming factors is not very significant. R. Tumas [4] established connection between the abundance of water hydrobionts and dispersed pollution in the rivers of Lithuania which are running through agricultural areas. Studies on run-off formation conditions in 17 rivers allowed to determine that the levels of pollutants of a nitrogenous and phosphorus origin in rivers are mainly influenced by climatic, topographic and geological factors. For instance, the levels of mineral nitrogen $\left(\mathrm{NH}_{4}^{-} \mathrm{N}+\mathrm{NO}_{2}^{-} \mathrm{N}+\mathrm{NO}_{3}^{-} \mathrm{N}\right)$ in two rivers of East Lithuania, the Širvinta and Žeimena, which differ in their runoff formation conditions, were $0,4-1,3 \mathrm{mg} / 1$ and $0,6-$ $2,1 \mathrm{mg} / \mathrm{l}$, respectively. In contrast, two rivers in Middle Lithuania, the Nevèžis and Lèvuo, contained much higher levels of mineral nitrogen compared to that in the Širvinta and Žeimena, although differences in phosphorus concentrations in these rivers were inconsiderable.

R. Pauliukevičius [5] performed an analysis on land utilities and average annual concentrations of nitrogen and phosphorus in 46 river basins in the period 19921994 and established a direct correlation between a farmed area and the concentration of both mineral nitrogen and phosphorus. The process of wash-out of these minerals is decreased relatively to the expansion of forests and swamps in river basins. After the draining of swamps, which cover around $5 \%$ of a river basin territory, the average annual concentration of total nitrogen increased by $50-60 \%$, whereas the effect of forest expansion was as twice as less efficient.

Foreign scientists analyse changes of water quality by taking into account both anthropogenic and environmental conditions. A. Grimvall and others [6] explored water quality changes in rivers in different East European countries (Estonia, Latvia, Hungary, Slovakia, and Poland) with relation to changes in intensity of anthro- pogenic activity in these areas. The obtained results show that, due to a decline in inensity of anthropogenic activity, an abrupt decrease of phosphate concentrations was observed in river waters, whereas no significant changes in concentrations of mineral nitrogen were detected. The authors also emphasize that it is very important to have data from long-term examinations. P. Stalnacke and others [7] examined changes in pollution of 6 major rivers inflowing into the Baltic Sea the (the Neva, Narva, Daugava, Nemunas, etc) during the period 1980-1993. It is estimated that every year river waters enrich the Baltic Sea with 825000 tons of mineral nitrogen and 41000 tons of phosphates. The authors note that the Baltic Sea is also additionally contaminated with nitrogen which originates in cities as well as from athmosferic precipitations from these areas.

\section{The purpose of investigation}

The main purpose of this study was to examine the quality of river water within three last decades (19742002) with expectation to find a relation between changes in the concentration as well as the total amount of biogenic matter and water abundance in rivers. These data would provide with a possibility to predict physical-geographical and climatic conditions of river basins in the South-East of Lithuania and future tendencies of alterations in water hydrochemical state.

\section{The object of investigation}

Three rivers in the South-East of Lithuania were chosen for the investigation: the Strèva, Šventoji, and Merkys. The main characteristics of their basins are summarized in Table 1 where the data from a monograph by B. Gailiušis and coauthors [8] were used.

\section{Methods}

For analytical purposes, we used the data of river water quality $\left(\mathrm{NH}_{4}^{+}, \mathrm{NO}_{2}^{-}, \mathrm{NO}_{3}^{-}, \mathrm{PO}_{4}^{3-}\right)$ provided by the Joint Research Center under the Ministry of Environment of the Republic of Lithuania [9] and the water discharge data presented in hydrological annals [8] of the Lithuanian Hydrometeorological Service.

Experimental analysis, during which water sampling was carried out with an increased frequency up to 3 times a month, was performed throughout the summer period of 2002 (June - September). The purpose of this experiment was to determine how the frequency of water sampling influences the assessment of average concentrations of biogenic matter throughout the examined period. Samples of water were taken from locations that are indicated in the Lithuanian National Monitoring Programme. Following the requirements of the Lithuanian standard LST EN 25667-1, samples were taken from littorals (1-1,5 $\mathrm{m}$ from the bank) as well as from middle river reaches and, while kept at $8-10{ }^{\circ} \mathrm{C}$, were delivered to the laboratory in 24 hours. 
148 L. Bagdžiūnaité-Litvinaitiene / Journal of Environmental Engineering and Landscape Management - 2004, Vol XII, No 4, 146-152

Table 1. Characteristics of analysed river watersheds

\begin{tabular}{|c|c|c|c|c|}
\hline \multirow{2}{*}{\multicolumn{2}{|c|}{ Characteristics of river watershed }} & \multicolumn{3}{|c|}{ Rivers } \\
\hline & & The Strèva & The Šventoji & The Merkys \\
\hline \multicolumn{2}{|l|}{ Total area of river watershed, $\mathrm{km}^{2}$} & 759 & 6888,8 & 4416 \\
\hline \multicolumn{2}{|c|}{ Area of river watershed up to the place of water sampling, $\mathrm{km}^{2}$} & 234 & 540 & 4300 \\
\hline \multicolumn{2}{|l|}{ Place of water sampling } & Semeliškès & Ukmergè & Puvočiai \\
\hline \multirow{3}{*}{ Area of different soils, $\%$} & heavy & - & 2 & 0,5 \\
\hline & medium & 63 & 73 & 32,5 \\
\hline & light & 27 & 25 & 67 \\
\hline \multirow{3}{*}{$\begin{array}{c}\text { Area of agricultural landed } \\
\text { property, } \%\end{array}$} & soil & 83,5 & 82,7 & 76 \\
\hline & garden & 1,8 & 2,5 & 2,4 \\
\hline & meadow & 14,7 & 14,8 & 21,6 \\
\hline \multicolumn{2}{|l|}{ Lakiness, \% } & 5,5 & 3 & 0,9 \\
\hline \multicolumn{2}{|l|}{ Marshiness, \% } & 13 & 16 & 10 \\
\hline \multicolumn{2}{|l|}{ Woodedness, $\%$} & 14 & 10 & 46 \\
\hline \multicolumn{2}{|c|}{ Annual run-off module, $\frac{l}{s \cdot \mathrm{km}^{2}}$} & 7,2 & 7,7 & 7,5 \\
\hline \multirow{3}{*}{ Long-term rainfall, mm } & annual & 678 & 588 & 625 \\
\hline & spring & 295 & 270 & 279 \\
\hline & summer & 140 & 123 & 140 \\
\hline
\end{tabular}

Concentrations of ammonium nitrogen were determined spectrometrically (LAND 38-2000), concentrations of nitrites - by molecular absorption spectrometry (LAND 39-2000), concentrations of nitrates - by using phenoldisulphate, and concentrations of phosphates spectrometrically, with the use of ammonium molybdate (LAND 58-2000).

Amounts of washed out substances within the period of investigation were calculated using the following formula:

$$
C=\frac{c Q t}{A \cdot 10^{5}}
$$

where $C$ denotes the amount of washed out substance ( $\mathrm{kg} / \mathrm{ha} /$ per period of investigation), $c$ is the concentration of biogenic matter $(\mathrm{mg} / \mathrm{l}), Q$ indicates the yield $\left(\mathrm{m}^{3} /\right.$ $\mathrm{s}), t$ is the duration of investigation period (s), $A$ denotes the area of river basin $\left(\mathrm{km}^{2}\right)$. Thus, using known water discharge values, we can calculate the run-off volume during given periods of time.

To examine the change dynamics of biogenic matter during spring and summer seasons, we chose April and September. This choice was motivated by the fact that April is a month with the largest water abundance
[8], whereas there is a low water abundance during the summer time. Since there are very scarce data available on water quality in July and August, September was chosen in this study. The data presented in Table 2 show monthly distribution of river run-off in Southeast Lithuania (years with different water abundance are compared).

We also used the data accumulated in the period of 1974-2002, during seasons of both plentiful (spring time, March-May) and low (summer time, June-September) water abundance. Using the method of regressive analysis [10] relationship among biogenic matter concentrations was established.

\section{Results}

Hydrological examination of the three selected rivers has revealed that the year 1994 was the most waterabundant for all the three basins. Water abundance probabilities calculated for the Strèva, Šventoji and Merkys were $2,33 \%, 9,85 \%$, and 2,38\%, respectively.

Water discharge in these basins in 1994 was 1,47, 1,46, and 1,31 times larger than average water discharge values obtained during a long-term period 1974-2002 $\left(1,65 \mathrm{~m}^{3} / \mathrm{s}, 40,8 \mathrm{~m}^{3} / \mathrm{s}\right.$, and $32,3 \mathrm{~m}^{3} / \mathrm{s}$, respectively). The

Table 2. Monthly distribution of river run-off in Southeast Lithuania during the periods of different wateriness

\begin{tabular}{|c|c|c|c|c|c|c|c|c|c|c|c|c|}
\hline \multirow{2}{*}{$\begin{array}{l}\text { Annual wateriness } \\
\text { expectation, } \%\end{array}$} & \multicolumn{12}{|c|}{ Months } \\
\hline & III & IV & $\mathrm{V}$ & VI & VII & VIII & IX & $X$ & $\mathrm{XI}$ & XII & I & II \\
\hline 25 & 11,3 & 16,8 & 9,6 & 6,6 & 5,2 & 5,5 & 5,4 & 7,0 & 8,5 & 8,1 & 8,0 & 8,0 \\
\hline 50 & 12,9 & 18,2 & 9,3 & 6,2 & 5,1 & 5,0 & 5,5 & 6,3 & 7,9 & 8,6 & 7,5 & 7,5 \\
\hline 75 & 12,6 & 21,6 & 8,8 & 6,0 & 5,1 & 4,7 & 5,5 & 6,2 & 7,3 & 8,2 & 7,1 & 6,9 \\
\hline 95 & 14,0 & 24,1 & 8,2 & 5,8 & 4,8 & 4,5 & 5,2 & 5,9 & 6,8 & 7,6 & 6,6 & 6,5 \\
\hline
\end{tabular}


Table 3. Seasonal run-off characteristics during the periods of different wateriness

\begin{tabular}{|c|l|c|c|c|}
\hline \multirow{2}{*}{ Seasons } & \multirow{2}{*}{ Rivers } & \multicolumn{3}{|c|}{ Seasonal run-off part from annual run-off, \% } \\
\cline { 3 - 5 } & & \multicolumn{3}{|c|}{ Seasonal wateriness } \\
\cline { 3 - 5 } & The Strèva & 38 & medium & low \\
\cline { 2 - 5 } & The Šventoji & 52 & 37 & 51 \\
\cline { 2 - 5 } & The Merkys & 38 & 30 & 36 \\
\hline \multirow{3}{*}{ Spring } & The Strèva & 24 & 21 & 28 \\
\cline { 2 - 5 } & The Šventoji & 13 & 20 & 22 \\
\hline
\end{tabular}

driest year in all the three river basins was 1976 with water discharge values 1,3-1,9 times lower than average yields of a long-term period (1974-2002). The year when water abundance reached average levels was different for each of the three rivers: 1999 - for the Streva (probability of 46,6 \%), 2001 - for the Šventoji (probability 47,5\%), and 1982 - for the Merkys (50,0 \%). Run-off modules during the period of investigation were similar among all the three rivers: 7,2 and 7,7 and 7,5 1/s km². Seasonal run-off percentage relative to annual run-off calculated during years with different water abundance characteristics is presented in Table 3.

According to the analysis of the hydrochemical regime for the period of 29 years, the Strèva, Šventoji and Merkys could be put among rivers with medium and little pollution. Nitrogen-containingions, such as ammonium, nitrites and nitrates, rarely exceed their largest allowable concentrations (the lowest allowable concentration (LAC), which are, accordingly, 0,5 mg/1, 0,03 mg/1 and 2,26 mg/1 in the examined river waters during the time of investigation. Probabilities that LAC of ammonium, nitrites and nitrates will be exceeded were, respectively: for the Strèva $-5,2 \%, 6,1 \%$, and 4,5\%; for the Šventoji - 6,9\%, 8,9\% and 5,5\%; and for the Merkys - 8,5\%, 6,1\% and 2,3\%. LAC of phosphates is $0,065 \mathrm{mg} / \mathrm{l}$. With regard to phosphates, probabilities that their concentrations will reach or exceed the LAC value $(0,065 \mathrm{mg} / \mathrm{l})$ were estimated $14,6 \%$, $17,0 \%$, and $27,2 \%$ for the Strèva, Šventoji, and Merkys, respectively.

In natural waters nitrogen-containing compounds undergo continual cycles of turnover. Ammonium ions are the product of biochemical oxidation of organic substances. Nitrifying bacteria, such as Nitrosomon and Nitrobacter, oxidize ammonium ions first into nitrites, and then to nitrates. The concentration of ammonium in the Strèva fluctuated between 0,02 and $0,68 \mathrm{mg} / 1$ during spring and summer seasons over the last 30 years, and LAC of this ion was rarely exceeded because of vegetation which intensively assimilates ammonium. Nitrites are detected in low amounts in natural waters because of their short half-life. During the period of investigation the concentrations of nitrites and nitrates in the Strèva waters fluctuated between 0,001 an $0,075 \mathrm{mg} / \mathrm{l}$, and between 0,64 and $2,82 \mathrm{mg} / \mathrm{l}$, respectively, whereas the concentrations of phosphates varied from 0,0014 to $0,64 \mathrm{mg} / \mathrm{l}$. In the other two rivers the corresponding concentrations of ammonium, nitrites, nitrates, and phosphates were as follows: $0,01-1,91 \mathrm{mg} / 1,0,001-0,08 \mathrm{mg} / 1$ and $0,014-4,7$ $\mathrm{mg} / \mathrm{l}$ - in the Šventoji, and 0,01-1,56 mg/1, 0,001-0,098 $\mathrm{mg} / 1,0,009-2,2 \mathrm{mg} / 1$ and $0,0-0,3 \mathrm{mg} / 1$ - in the Merkys. Noteworthy, nitrate concentrations never exceeded the LAC value in the Merkys during the period of investigation.

Comparative analysis of changes in nitrogen and phosphate concentrations in the examined rivers has revealed that the concentrations of these ions are more likely to exceed the LAC values in the years of either a low or medium water abundance. In the years of a low water abundance the probability that LAC levels will be exceeded in the Strèva was 5,3\%, 3,5\%, 6,8 \% and $2,9 \%$ for ammonium, nitrites, nitrates, and phosphates, respectively, whereas in the years of a medium water abundance the probability was $6,4 \%, 5,8 \%, 5,1 \%$ and $74 \%$, respectively. LAC of ammonium in the Šventoji in the years of a low and medium water abundance was not exceeded. As for the Merkys, LAC of mineral nitrogen in the years of a low water abundance was also not exceeded, whereas probability to exceed LAC of phosphate was $22,9 \%$. LAC excess probability in the Merkys in the year of a medium water abundance was $8,1 \%$ for ammonium, 5,1\% for nitrites, whereas excess of LAC was not observed for nitrates. LAC of mineral nitrogen in the years of a high water abundance was not exceeded in the Strèva and Šventoji, whereas LAC excess probability for ammonium and nitrates in the Merkys was $0,3 \%$ and $1,3 \%$, respectively (no excess of the LAC value was detected for nitrites). Probability that phosphate concentrations will exceed LAC in the year of a high water abundance was estimated 12,2\% for the Šventoji, and 26,7 \% - for the Merkys, but no excessive concentration was detected in the Streva.

Analysis of data on average annual concentrations of mineral nitrogen and phosphorus throughout the period of many years has revealed that there is no considerable relationship between water abundance and the concentration of elements (see Fig 1). However, in the case of the Strèva the concentration of both mineral nitrogen and phosphorus showed a decrease in parallel to a decrease in water abundance. This tendency was not observed in other rivers. The coefficients of correlation between the concentration (the significance level was less than 0,05 ) of biogenic matter and water abundance fluc- 

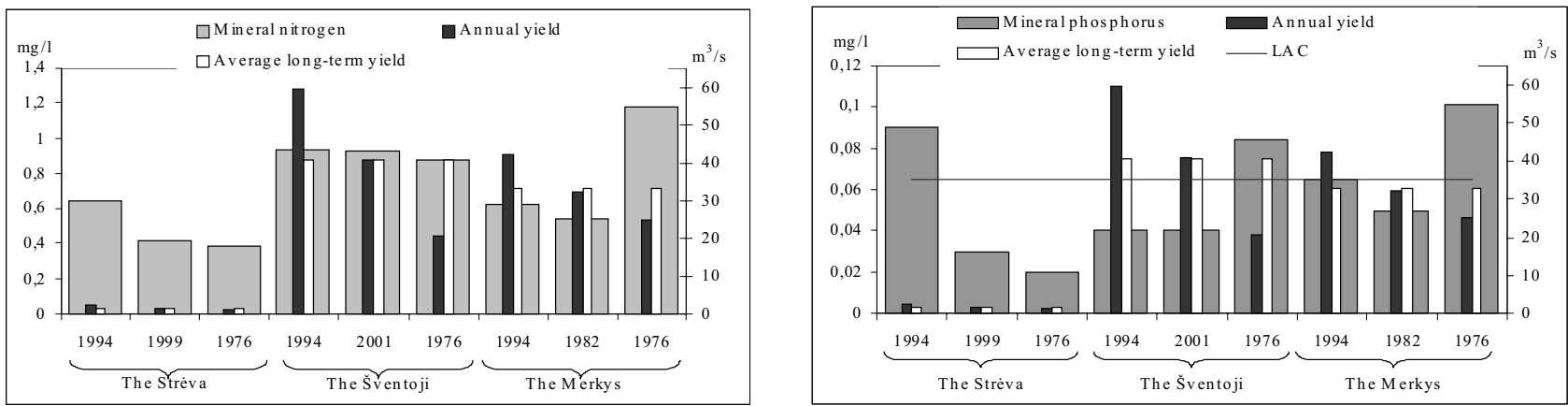

Fig 1. Change in concentrations of mineral nitrogen (a) and phosphorus (b) in the Streva, the $\square$ ventoji and the Merkys waters during periods of high, medium and low wateriness
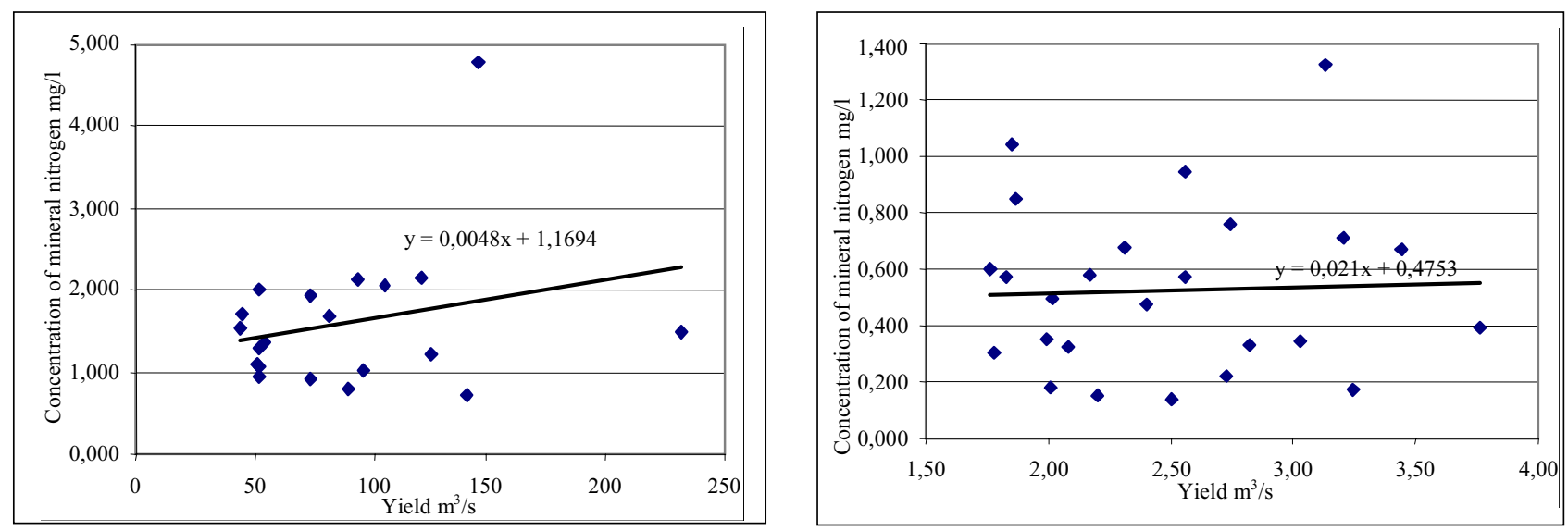

Fig 2. Diagram of connection between mineral nitrogen concentrations and yields in the Strèva (a) and the $\square$ ventoji (b) waters in April

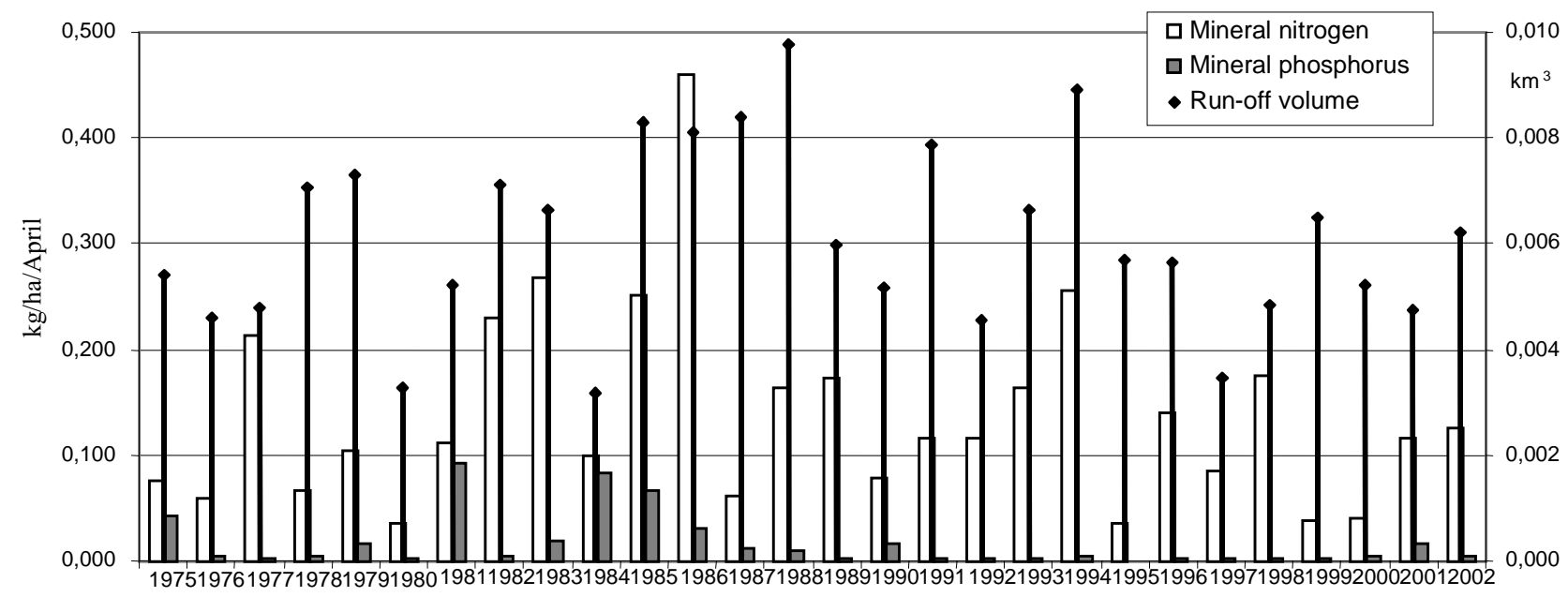

Fig 3. Change of biogenic matter quantities and run-off volume in the Strèva in April

tuated from 0,04 to 0,1 indicating that there is no strong relationship between these two parameters.

Since there was no obvious connection detected between average manual concentrations of biogenic matter and water discharge, next it was decided to compare these two water characteristics between April and September (i e between the periods of a high and low water abundance) throughout the period of 29 years. As a result of this analysis, relationship between the con- centrations of biogenic matter and water discharge was a little tighter though still week (Figs 2, 3). In April the coefficients of correlation between mineral nitrogen and water discharge and mineral phosphorus and water discharge were, accordingly, 0,03 and 0,26 for the Strèva, 0,26 and 0,14 for the Šventoji, 0,11 and 0,02 for the Merkys, whereas in September corresponding pairs of correlation coefficients were as follows: 0,23 and 0,15 , 0,34 and $0,31,0,004$ and 0,1 . 


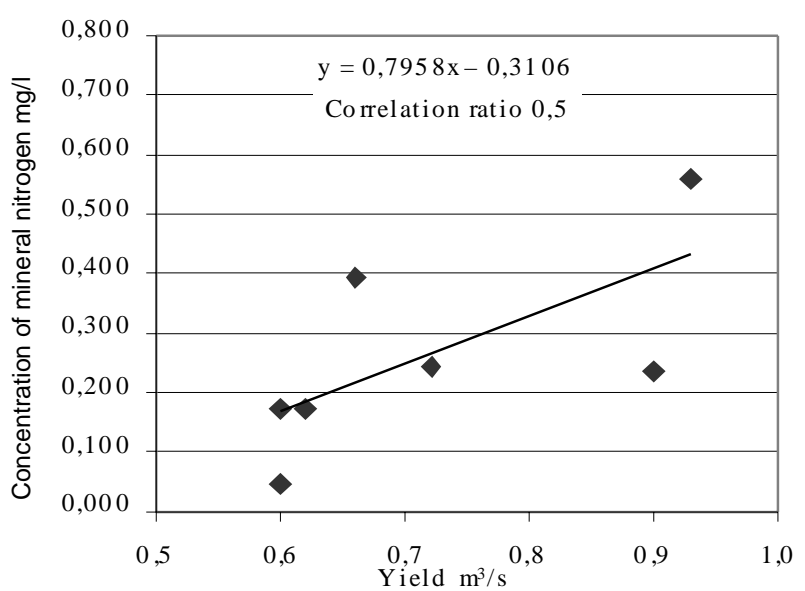

a

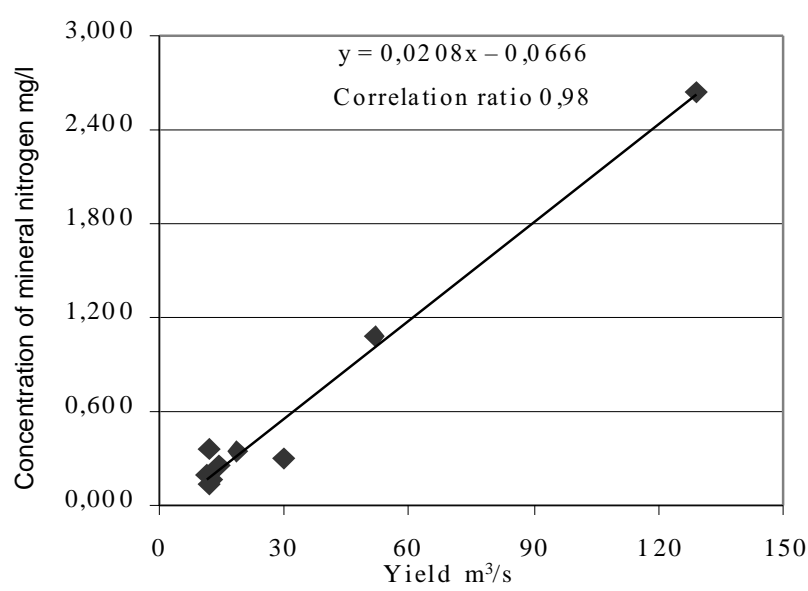

$\mathrm{b}$

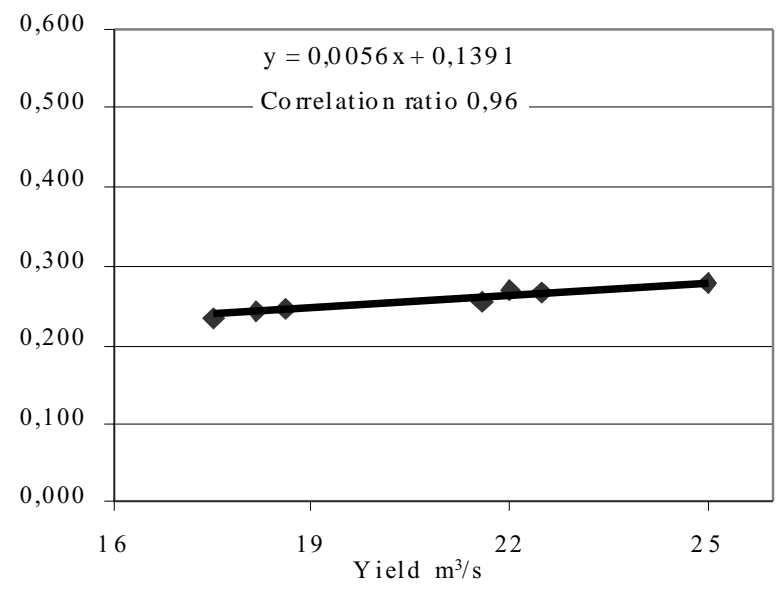

c

Fig 4. Diagrams of regresional equations between mineral nitrogen concentrations and yields in the Strèva (a), the Šventoji (b) and the Merkys (c)

Analyses of changes in biogenic matter amounts and run-off volumes are presented in Fig 3. These data show that, throughout the period of 30 years, the volume of water run-off in the Streva changed in the range of $0,01-$ $0,029 \mathrm{~km}^{3}$ in April, and $0,005-0,016 \mathrm{~km}^{3}$ in September, the amounts of washed out mineral nitrogen and phosphate were, respectively, 0,11-1,41 kg/ha and 0,019 $0,4 \mathrm{~kg} / \mathrm{ha}$ in April, and $0,004-0,2 \mathrm{~kg} / \mathrm{ha}$ and $0,003-$ $0,27 \mathrm{~kg} / \mathrm{ha}$ in September. As for the Šventoji, the runoff volume changed from 0,34 to $1,17 \mathrm{~km}^{3}$ in April and from 0,07 to $0,46 \mathrm{~km}^{3}$ in September, whereas washout of nitrogen and phosphorus in April was, accordingly, $0,808-2,89 \mathrm{~kg} / \mathrm{ha}$ and $0,010-0,08 \mathrm{~kg} / \mathrm{ha}$, and in September - 0,009-1,07 kg/ha and 0,0009-0,143 kg/ha. Runoff volume in the Merkys fluctuated from 0,24 to $1,74 \mathrm{~km}^{3}$ in April and from 0,13 to $0,38 \mathrm{~km}^{3}$ in September, and the washout of mineral nitrogen and phosphorus in April was, respectively, 0,15-2,95 kg/ha and 0,024-0,687 kg/ha, whereas in September - 0,05$0,58 \mathrm{~kg} / \mathrm{ha}$ and $0,005-0,55 \mathrm{~kg} / \mathrm{ha}$. In all the examined rivers the water run-off is lower in September, and the amount of washed out matter is also lower compared to that of other months.

A plausible explanation for observed weak connec- tion between the amounts of washed out mineral nitrogen and phosphorus and run-off volumes can be possibility that water sampling, which was carried out once a month, may incompletely represent an exact dynamics of changes in the concentrations of substances.

The results obtained in the summer of 2002 are presented in Fig 4. These data demonstrate a direct interdependence between biogenic matter concentrations and water discharge, with the coefficients of correlation 0,86, 0,99, and 0,63 for the Strèva, Šventoji, and Merkys, respectively. Long-term studies are needed in order to foresee any consistent pattern which would provide for forecasting.

\section{Conclusions}

1. Analysis of manual data on mineral nitrogen and phosphorus concentrations and water discharge in rivers obtained during the period 1974-2002 allows us to conclude that there is no dependence between the substace concentrations and river water abundance. This was in line with the regressive analysis data showing changes in correlation between 0,04 and 0,1 .

2.Analysis of the same type of data from the same 
period but keeping within the bounds of two seasons with different water abundance, which were represented by April (high water abundance) and September (low water abundance) revealed a considerably closer correlation between the substance concentrations and water discharges. The coefficients of the correlation varied from 0,3 to 0,6 .

3. After accomplishing additional sampling of surface waters ( 3 times a month) and after their analysis, it was determined that dependence between nitrogen and phosphorus concentrations and yields is rather close, the coefficients of correlation changed from 0,5 to 0,99 .

\section{References}

1. Šileika A. S. Agriculture Nitrogen Impact on Water Quality in Lithuanian Rivers. Environmental research, engineering and management, No 1(2). Kaunas, 1996, p 22-30.

2. Šileika A. S.; Berankienė L. Evaluation of Lithuanian river quality changes. Water management engineering, No 3(25). Kèdainiai, 1997, p. 194-194.

3. Tumas, R. Farming and river water quality. Environmental Engineering (Aplinkos inžinerija), No 2(8). Vilnius, 1997, p. $25-30$.

4. Tumas R. Ware ecology: hydrochemical and hydrobiological evaluation of Lithuanian rivers. Water management engineering, No 14(36). Kèdainiai, 2001, p. 41-47.

5. Pauliukevičius H. Žemės naudmenų transformacijų poveikis azoto ir fosforo koncentracijoms upiu vandenyje. Water management engineering, No 13(35). Kèdainiai, 2000, p. 24-29.

6. Grimvall A.; Stalnacke P.; Tonderski A. Time scale of nutrient losses from land to sea - a European perspective. Ecological Engineering, No 14, 2000, p. 363-371.

7. Stalnacke P., Grimvall A., Sundbland K. Estimation of riverrine loads of nitrogen and phosphorus to the Baltic Sea, 1970-1993. Environmental Monitoring and Assessment, No 58. Netherlands, 1999, p 173-200.

8. Gailiušis, B.; Kovalenkovienè, M.; Jablonskis, J. The Lithuanian rivers. Hydrography and runoff. Kaunas, 2001, p. 195.

9. Data of investigation of quality in Lithuanian rivers. Department of Evironmental Protection of Republic of Lithuania. Vilnius, 1974-2002.

10. Annual reports on hydrological data. Hydrometeorological Service of Lithuania at the Ministry of Environment. Vilnius, 1974-2002.

\section{BIOGENINIŲ MEDŽIAGŲ POKYČIŲ DINAMIKA PIETRYČIŲ LIETUVOS UPIŲ VANDENYSE SKIRTINGO VANDENINGUMO LAIKOTARPIAIS}

\section{Bagdžiūnaitè-Litvinaitienè}

$\mathrm{S}$ a $\mathrm{n} \mathrm{t} \mathrm{r}$ a $\mathrm{u} \mathrm{k}$ a

Vandens apsauga yra viena iš visapusiškiausių reguliuojamų ES aplinkos apsaugos sričių. Norint prognozuoti vandens ekosistemų būklę būtina i̇vertinti jų ilgalaikę kaitą.

Straipsnyje nagrinèjama trijų Pietryčių Lietuvos upių (Strèva, Merkys, Šventoji) vandens kokybė per tris pastaruosius dešimtmečius. Analizuota priklausomybė tarp biogeninių medžiagu (mineralinis azotas ir fosforas) koncentracijų bei kiekių kitimo ir upių vandeningumo. Tiriant 30 metų laikotarpio metinius biogeninių medžiagų koncentracijų bei debitų duomenis nustatyta, kad priklausomybès nèra. Tačiau nagrinejjant tam tikrais ivvairaus vandeningumo laikotarpiais, išskiriant mėnesiais, akivaizdi sąsaja, koreliacijos koeficientas kinta nuo 0,3 iki 0,6 . Paėmus papildomus paviršinių vandenų mėginius (3 kartus per mėnesi) nustatyta, kad priklausomybė tarp biogeninių medžiagu ir debito yra ryški, koreliacijos koeficientas kinta nuo 0,5 iki 0,99 .

Raktažodžiai: mineralinis azotas, mineralinis fosforas, nuotèkio tūris, debitas.

\section{ДИНАМИКА БИОГЕННЫХ ВЕЩЕСТВ В ВОДАХ РЕК ЮГО-ВОСТОЧНОЙ ЛИТВЫ В ПЕРИОДЫ РАЗНОЙ ВОДОНОСНОСТИ}

\section{Л. Багджюнайте-Литвинайтене}

$\mathrm{P}$ е 3 ю $\mathrm{M}$ e

Водная защита - одна из наиболее всесторонне регулируемых областей контроля за окружающей средой в ЕС. Чтобы прогнозировать статус водной экосистемы, необходимо оценить ее долгосрочные изменения. Рассмотрено качество воды трех рек юго-восточной Литвы (Стревы, Меркиса, Швянтойи) в течение трех прошлых десятилетий. Проанализирована зависимость между водоносностью рек и изменением количества и концентрации биогенных веществ (минерального азота и фосфора). На основании анализа ежегодных данных о концентрации биогенных веществ и дебита в течение 30-летнего периода было установлено, что такой зависимости не существует. Однако она появляется, когда анализируются отдельные периоды разной водоносности по месяцам, коэффициент корреляции колеблется от 0,3 до 0,6. После взятия дополнительных выборок (3 раза в месяц) поверхностных вод было установлено, что зависимость между биогенными веществами и дебитом является сильной, коэффициент корреляции колеблется от 0,5 до 0,99 .

Ключевые слова: минеральный азот, минеральный фосфор, объем сточных вод, дебит. 